\title{
Gender Mainstreaming Analysis At The Management Level
}

Salma Masood Khan, Sarhad University of Science and IT, Peshawar, Pakistan Dr. Mohammad Iqbal, Sarhad University of Science and IT, Peshawar, Pakistan

\begin{abstract}
It was an exploratory study that was conducted with the main objectives to: provide basic information to stakeholders and planners about gender imbalance and its implications for Khyber Pakhtoonkhwa (KP) province and Pakistan. The study attempted to: discover the existing gender scenario in the management cadre of public sector of the province; identify barriers and problems to gender equity and equality in the management roles; and suggest ways and means to remove gender disparity at the management level in the sampled devolved departments of social sector of KP. Survey Questionnaires, interviews and stakeholders' workshop were used as tools to collect data from 117 respondents of the sampled departments. Main causes of low female participation at higher level included lack of opportunities, inadequate facilities to female officers, rising element of insecurity in the province, men specific positions, discriminations and socially evolved gender bias. On the basis of results and findings a couple of suggestions like organizing gender awareness sessions, ensuring implementation of sanctioned quota, promotion of higher education for women, capacity development and incentives for potential female officers and revival of posts of female District Education Officers, have been made.
\end{abstract}

Keywords: gender; discrimination; analysis; mainstreaming; managerial cadre; equality; development; Khyber Pakhtoonkhwa

\section{INTRODUCTION}

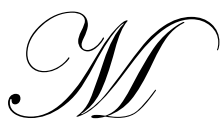

en and women are important constituents of every society, which flourishes adequately when both participate actively in its development process. When a society fails to engage them fully, productively and constructively, it becomes difficult to achieve goals of growth and development at individual, local and national levels. Klien and Nestvogel (1992) observed that there was an adequate evidence to demonstrate that when both men and women got equal opportunities, economies grew faster, the poor moved quickly out of poverty, and well being of men, women and children got enhanced. But when any one of them burdened the other, the growth and efficiency of both was hampered. Women in underdeveloped areas generally had been leading dependent and disadvantaged life with very little economic contribution.

Resultantly, gender inequalities have emerged as a global concern, found pervasively and persistently throughout the world particularly in underdeveloped areas like Asia and Pacific region, with women concentrated in jobs having low security, few occupational choices, low pay, poor working conditions, low status and low bargaining power in the work market. (ILO-GEMs 2004) This all had been perpetuating, as development approaches had mostly targeted men, and saw only them as heads of households, farms and businesses. The women had been seen merely as housewives and secondary earners, very marginalized, despite the fact they constituted more than half of world's population. (Bandu \& Singh, 2003) As per UN assessment, some progress had been made in the recent past but there still were profound gaps to adequate gender equality. Walby (2005) reported that women and girls still represented $2 / 3^{\text {rd }}$ of the world's illiterates, $70 \%$ of the 130 million children not enrolled in schools were girls. In underdeveloped countries fewer girls than boys finished primary school, lesser passed high schools and even lesser completed university education. Aksoronkool (2002) stated that ordinary women in addition to poverty, educational deprivation and financial discrimination, commonly faced oppression, superstition, fatalism and die- 
hard stereotypes. They mostly tended to have low self esteem and thought nothing of their economic contribution and accepted the idea of self sacrifice and self negation.

\section{GENDER SCENARIO AT PAKISTAN}

The national scenario of Pakistan represents more serious gravities of gender discrimination, than found internationally, arising out of illiteracy, customs, traditions, taboos, biases and financial constraints. Women comprise nearly half of the total population but due to limited efforts made by the government and society at large they lag behind in progress by all social indicators. As per UNDP's (2003) Gender Development Index (GDI), Pakistan ranks $120^{\text {th }}$ out of 144 countries; and as per Gender Empowerment Measure (GEM) it ranks $64^{\text {th }}$ out of 78 countries. GDI takes into account Human Development Index indicators as per gender, including life expectancy, educational attainment and income; and GEM measures gender inequality in economic, political and decision making participation. At Pakistan national and provincial resources are not increasing at pace at which population is multiplying, leading to a persistently increasing void between demands \& supplies at all levels including the management level. Although, development interventions with limited resources had claimed to be neutral, but these had benefited those who were better off, educated, well informed and more accessible. In Pakistani society all of the above were more likely to be men than women. Hence gender disparities are getting very pronounced whether judged through GDI, GEM or political managerial participation of men and women

Table A: Gender Based Analysis Of Political And Managerial Women Participation At Pakistan

\begin{tabular}{|l|c|}
\hline Women employed by the Federal Government (9387 out of 175189) & $5.4 \%$ \\
\hline Women in Federal Government at Ministerial level (\% of total) & $11 \%$ \\
\hline Female Legislators, senior officials, and managers (\% of total) & $9 \%$ \\
\hline Total Number of seats for women in all tiers of Local Government & $33 \%$ \\
\hline Total Number of seats for women in Senate, National \& Provincial Assemblies & $17 \%$ \\
\hline
\end{tabular}

Source: State of Human Rights in 2004 HRCP

Recently, the political participation of women has slightly improved due to the quota system with reserved seats for women, like total number of seats in all tiers of local government has risen from $6 \%$ to $33 \%$; and at National Assembly has gone upto 21\%; yet the situation is far from satisfactory. Half of the country's female population manages to get only $21.05 \%$ representation in the National Assembly, and between 18-19\% in all the provincial assemblies!

Table B: Women In The National And Provincial Assemblies, 2008

\begin{tabular}{|l|c|c|c|c|c|}
\hline \multicolumn{1}{|c|}{ Elected On } & General Seats & Reserved Seats & Total & Total Seats In Assembly & \%Age Of Total Seats \\
\hline National Assembly & 12 & 60 & 72 & 342 & $21.05 \%$ \\
\hline Punjab & 6 & 66 & 72 & 371 & $19.40 \%$ \\
\hline Sindh & 4 & 29 & 33 & 168 & $19.64 \%$ \\
\hline Khyber PakhtoonKhwa & 1 & 22 & 23 & 124 & $18.54 \%$ \\
\hline Balochistan & 1 & 11 & 12 & 65 & $18.46 \%$ \\
\hline Total & $\mathbf{2 4}$ & $\mathbf{1 8 8}$ & $\mathbf{2 1 2}$ & $\mathbf{1 0 7 0}$ & $\mathbf{1 9 . 8 1 \%}$ \\
\hline
\end{tabular}

Source: Election Commission of Pakistan 2008

The Government of Pakistan has realized that the social indicators can be improved if gender disparities are addressed seriously. In order to correct the alarming inequalities the Government has made serious pledges in light of the international commitments, including MTDF (Mid Term Development Framework), NPA (National Plan of Action), NPDEW (National Policy for the Development and Empowerment of Women), GRAPs (Gender Reform Action Programs-National and Provincial), TA2 (Decentralization Support Program), and GSP (Gender Support Program). It is believed that how so ever slowly but their implementation would lead to positive societal changes. 


\section{GENDER SCENARIO IN KHYBER PAKHTOONKHWA (KP) PROVINCE}

In the province of KP the situation is much graver and the problem of gender is wedded by and large to strong cultural and social customs, traditions and taboos. The process of development has mostly revolved around men of the society; failing to fully involve women as partners of development. Klein and Nestvogel (1992) wrote that ever since its establishment, Pakistan, stuck with poverty, illiteracy, political instability and conflict on its borders, could not pay due attention to women development policies generally, and to improvement of managerial structural set up with gender perspective specifically. As a result country's human development indicators \& particularly of provinces like Khyber Pakhtoon- khwa and Balochistan were among the lowest in the country, with peculiar socio-cultural fabric of the provinces perpetuating the status quo. Similarly Brouwers and Zafar (1999) stated, "Access of Pakhtoon women to opportunities, resources and decision making positions is constrained by feudal, tribal and patriarchal cultural norms, which view women as the responsibility of the male members of the family, tribe and community, and place restriction on their mobility and decision making role in and out of home activities. This is endorsed by the low literacy rate of females of KP $(18.82 \%)$ as compared to female literacy rate of the country $(32.02 \%)$ versus literacy rates of males of KP $(51.39 \%)$ and of Pakistan (54.81\%). The difference in case of females is very profound $(18: 32,51: 54)$ as is evident from the following table:

Table C: Selected Development Indicators For Pakistan \& KP

\begin{tabular}{|l|l|l|}
\hline Indicator & Pakistan & KP \\
\hline Literacy Ratio (Both Sexes) & 43.92 & 35.41 \\
\hline Male Literacy Ratio (\%) & 54.81 & 51.39 \\
\hline Female Literacy Ratio (\%) & 30.02 & 18.82 \\
\hline
\end{tabular}

Source: SDP, FATA, 2006 (Literacy rates as per 1998 census; the rest for 2003)

\section{WHY GENDER MAINSTREAMING?}

The whole scenario of women's status explains adequately why the managerial and administrative cadres have inadequate representation of women. Presumably the male policy makers failed to accurately assess in its true perspective the needs and requirements of women as active participants and beneficiaries of the development policies. Along with other factors, minimum presence of women in the managing and implementing positions has in all probability attributed to the existing overall poor female condition.

Since very long the dominant approach and practices of management have marginalized women to a great extent. Most of the key positions appear to be held by men in nearly all departments of public and private sectors. The heads are conveniently presumed to be men and conceptually female leadership is confined to services, like nursing, teaching, secretarial work, household and child care. Gender mainstreaming is important for equal inclusion of men and women in all aspects of development to promote economic and social efficiency and sustainability. Promoting both capable men and women to the managerial and administrative level not only can ensure the optimum utilization of all talents but will also motivate other females to strive for the top positions.

\section{GENDER AND MANAGEMENT}

Research in the field of gender and management had been developing in UK and US since 1980s. Much of the work in this field had concentrated on gaining an accurate picture of the conditions under which women work at all levels in all sectors of society. Research into gender and management, has given rise to analyses of organizational discourse, its constitutive base and practices. Different surveys and studies have ventured to study and ascertain the role of women in the managerial cadre. Marshal (1995) had observed that this research had lead to a critique of organizational arrangements focusing on discrimination and the barriers women experience in managerial contexts. KK's report (2006) on gender and development, stated, Institutions in general are ossified and archaic, fully resisting change. The cultural biases against women in management make the individuals and institutions implicitly resist the professional progression of women. 
Loutfy (1992) observed that women were under represented in highly paid occupations; and it took them longer to reach there. They were usually in middle management. Loutfi felt that women's frequent failure to reach the top had been largely due to lack of confidence and aspirations, which was further due to the non supportive attitude of the society. Davidson and Cooper (1989) also observed, "While men and women managers often share common stressors of work, female managers are faced with additional pressures from the home and social environment, not experienced by male managers." Kjeldsen (2000) as well observed that assertive, power seeking behaviour in men was appreciated as traits of leadership, but such qualities in women were judged as traits of hostility and aggression, putting women in a non win situation. The judgment about what is right or wrong is made mostly not by women but by men and society. These attitudes, low capacity and cultural inhibitions together have kept managerial participation of women to the bare minimum.

\section{HYPOTHESES OF THE STUDY}

The following hypotheses were developed for the study:

- $\quad$ Gender balance does not exist in the managerial strata of the public sector of KP

- $\quad$ Females working in the Public Sector of KP do not get due importance, are often denied fair access to opportunities and chances of promotion at par with their male counterparts

- Working environment is not women friendly, rather inhibits the professional development and adequate promotion of women to the key managerial positions.

- There are different rules and policies withholding women from optimum utilization of their talents as managers and administrators.

\section{POPULATION AND SAMPLE}

The personnel in the managerial and administrative category and potential managers of the KP Province's devolved departments in the social sector were the population of this study. The study chose purposive sample, including five devolved departments of the social sector including Agriculture, Education (Schools and Literacy), Health, Information Technology, Social Welfare, Zakat, Usher and Women Development. Precisely one hundred and seventeen officers from these departments were chosen as sample of the study.

\section{METHODOLOGY \& DATA COLLECTION SOURCES}

It was a descriptive exploratory study that attempted to analyze gender equality, balance and mainstreaming at the management level, by investigating female participation in public managerial service, as compared to the male participation at the same level in KP province of Pakistan. The data was collected from the randomly chosen five devolved departments in the social sector and the study was delimited in scope to the management and administration cadre of these five departments. Both primary and secondary sources were used. Eighty six subjects were approached through a questionnaire, twenty three were involved through a stakeholders' workshop and eight senior officers were interviewed in detail. The sample's size was kept fairly large to promote reliability and validity. For quantitative data questionnaires were used as primary source and qualitative data were obtained from interviews, discussions and stakeholders' workshop. The secondary data were collected from the governments' website, different surveys, census and reports.

\section{PILOT STUDY}

Preliminary testing of the instrument was done in order to check its effectiveness. The mini pilot interaction helped in minimizing errors. Four copies of the questionnaires were given to four competent officers of the School and Literacy Department; whose input helped in refining the tool.

\section{DATA ANALYSIS AND DISCUSSION}

The data obtained through interviews and focused group discussions of stakeholders' workshop and the responses of surveyed informants were converted into percentages and analyzed with the help of tables, diagrams 
and graphs. Responses to the question about the number of females occupying administrative and managerial positions at grade 18 and above in the sampled departments revealed the following facts:

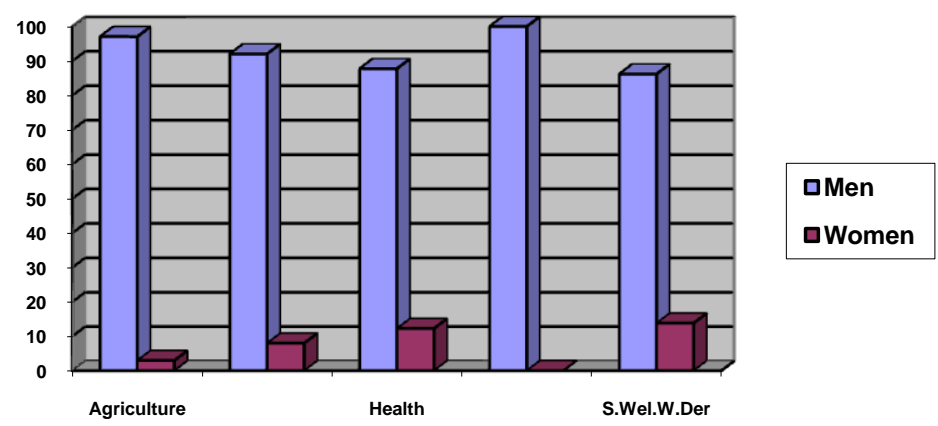

Figure A: Percentage Of Women VS. Men At Managerial \& Administrative Positions The data reflected nil representation of females at the top strata of IT, very negligible at the Agriculture sector, and very low at Women Development, Health, Education, Social Welfare, Zakat and Usher Departments.

Females in the top level management and administration category including Secretaries, Additional and Special Secretaries, Deputy Secretaries, Directors and Senior Planning officers were found to be very few. The number of mid level administrators including Section Officers, Planning Officers and Deputy Directors was also very small.

Main reasons blocking females' promotion to senior positions were found to be quite a few. Maximum respondents i.e. $42 \%$ considered 'lack of opportunities' $19 \%$ identified 'Inadequate facilities for female officers', and $15 \%$ considered 'men specific positions' as main reasons for the low female representation. $13 \%$ cited deliberate discrimination and socially evolved gender bias and $11 \%$ held females responsible for the low induction as they were not interested in senior administrative posts due to inadequate family support.

Enquiry about specific problems faced by female officers resulted in identification of twenty five different types of problems grouped and reflected in Figure B. An overwhelming majority identified non-conducive working conditions (insecurity and fear of terrorist activities, the most recent and strongest additions), followed by socio cultural inhibitors. The male chauvinist attitude of the co-officers, failure to recognize the needs of females by seniors, non acceptance of women as bosses; and gender bias were expressed as important factors in this respect.

Socio cultural problems included lack of support by male family heads, work demands clashing with domestic duties, postings to far away places, frequent transfers and high risk associated with long office hours due to high level of insecurity in the province resulting from recent terrorism waves. Male dominated restrictive environment, absence of female role models, traditional values and taboos and 'purdah' system or restricted interaction with males were also identified as prominent inhibitors.

Responses to the probe about problems posed by females to the department, a vast majority reflected very vividly that no problems had been posed by female employees. However some of the problems as given in Table E, included resistance to hard areas transfers, absenteeism owing to family responsibilities; over politeness, comparatively weaker control over male subordinates; demand of separate offices by females and being extra strict with female subordinates. 


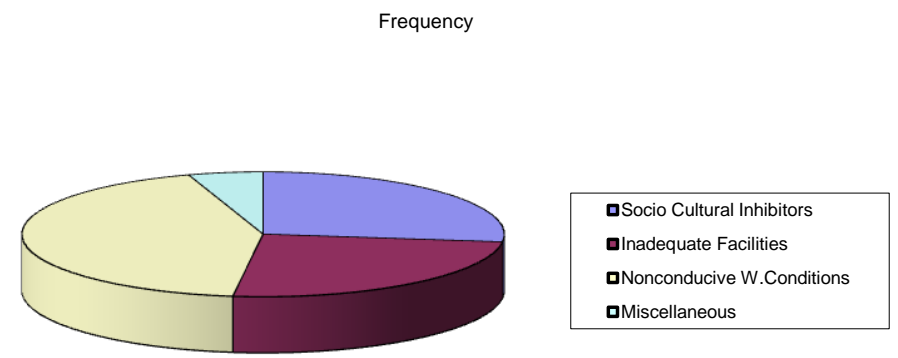

Figure B: Major Problems Faced By Female Officers

The analysis indicated that major problem cited by $52 \%$ was non conducive working environment, and $22 \%$ felt it were socio cultural inhibitors that held back women from managerial progression. $18 \%$ considered inadequate facilities \& $8 \%$ referred to different miscellaneous problems faced by female officers

Table E

\begin{tabular}{|c|c|c|}
\hline S.N & Problems Posed By Females Officers To Departments & Percentage \\
\hline 1 & No problems & 54.65 \\
\hline 2 & Resisting transfers to remote areas & 15.11 \\
\hline 3 & Absenteeism due to family responsibilities & 12.79 \\
\hline 4 & Inability to work late hours with enhanced seniority \& responsibility & 10.47 \\
\hline 9 & Miscellaneous & 6.98 \\
\hline
\end{tabular}

All respondents without fail expressed that the service rules were very non discriminatory and provided equal opportunities to both men and women for promotion to senior positions.

\section{OUTCOMES OF THE STUDY} drawn:

Based on the analyses of data; review of literature, discussions and results, the following conclusions were

1. The study revealed a big gap of gender inequality supported by $91 \%$ of respondents, biased towards males in the administrative and managerial positions. This confirmed study's first assumption that gender balance does not exist in the managerial strata of the selected departments in the public sector of KP Province.

2. Non gender discriminatory nature of rules and regulations was supported by $100 \%$ of the respondents. This negated the second assumption that females working in the Public Sector of KP are often denied fair access to opportunities and chances of promotion at par with their male counterparts.

3. The study confirmed that the working environment is non conducive for women; restraining female officers avail the opportunities granted through the unbiased rules and regulations. Inadequacy of facilities, absence of women specific supports, non supportive attitudes, heavy job demands clashing with domestic demands proved inhibitive, making the females avoid upward progression and proved the third hypothesis of the study by support of $86 \%$ respondents that working environment is not women friendly, hampering professional development and promotion of women to key managerial positions.

4. The study further revealed that traditions, customs and cultural taboos coupled with low level of education proved obstructive to gender equality at the managerial level, and endorsed the fourth hypothesis that there are different factors withholding women from optimum utilization of their talents, creating inhibiting ethos where female administrators fail to assert themselves in an impeccable manner to pave the way for other females in the managerial strata of the public sector of Khyber Pakhtoonkhwa province. 


\section{SUGESTED MEASURES}

There is a dire need to reduce existing imbalances to promote gender equality in the public sector of KP province. Policies need to be reviewed to make them gender friendly, through gender sensitization and gender mainstreaming practical trainings for policy makers. Increasing quota for women at decision making forums and at all tiers of management along with absolutely utilizing sanctioned quota in letter and spirit has to be ensured.

In order to promote sustainable solutions capable female officers need to be facilitated through incentives like daycares and transport, conducive working environments, and inland and foreign capacity building courses for upward progression. Promotion of female education at all levels throughout the province, grant of scholarships to capable females for higher and technical education, bringing awareness about rights of women; uncovering hidden biases limiting women's ability to work actively and radical attitudinal change towards women emancipation in public through media need to be promoted. Availability of women managers in the education department (that has the maximum number of female employees), can be enhanced by reviving abolished posts of Female EDOs (Executive District Education officer).Media need to develop a sensitized code of ethics to depict modern and challenging roles of women and avoid reinforcing the gender stereotypes. It is hoped that with the implementation of these measures, amicable gender balance with far reaching positive impacts can be promoted in the management sector of Khyber Pakhtoonkhwa province of Pakistan.

\section{ABOUT THE AUTHORS}

Prof. Dr. Mohammad Iqbal is working as Head of Department of Education at Abasyn University of Khyber Pakhtoonkhwa, Pakistan, and a visiting faculty of Sarhad University of Science and Information Technology, Peshawar. He earned his PhD in Educational Administration from the Pennsylvania University, USA in 1990 and completed a course in HRM in 1986 from ADL Management Edu. Institute, Boston, Massechusetts, USA. He has worked as College Principal, Deputy Secretary Education and Consultant for Educational Projects. He has produced fifteen M. Phil graduates and eight PhD scholars are about to be graduated. He so far has contributed many articles in different journals and dailies.

Salma Masood Khan is working as a Principal and Consultant Education, and has worked as Gender Lead trainer for UNDP, at Peshawar, and is working as HR training consultant at Institute of Management Sciences, Peshawar, Pakistan. She has completed her PhD in Education from Sarhad Institute if Science and Information Technology. She has done different courses from Portland State University, Oregon, USA, and Bradford University, UK. She has widely worked and written for women, education and different social issues.

\section{REFERENCES}

1. Aksornkool N, Joerger C, and Taylor E, (2002), Gender Sensitivity, UNESCO Place de Fontenoy, Paris, France

2. Bandu, A. \& Wickrama Singh, (2003) Gender Dimensions in Disaster Management- A Guide for South Asia, Siri Lanka: ITDG South Asia Publications

3. Brouwers, R. and Zafar F. (1999), Evaluation of the Education Component of Social Action Program Project Gender Equity in Education in Pakistan Vanguard Books Ltd, Lahore, Pakistan

4. Davidson and Cooper (1989), Gender and Administrational aspects, Blackwell, Cambridge USA

5. Election Commission of Pakistan,(2008) Adam Carr's Electoral Archive

6. FATA Secretariat (2006) FATA Sustainable Development Plan. Peshawar, Pakistan, Civil Secratariat

7. Human Rights Commission of Pakistan (2004) State of Human Rights in 2004 Islamabad, Pakistan. HRCP

8. International Labour Organization (2004) Promoting Gender Equality at Work. Bangkok: ILO Regional Office for Asia and Pacific

9. ILO (2004) Breaking through the Glass Ceiling: Women in Management Update 2004. Bangkok, ILO Regional Office for Asia and Pacific

10. Kjeldsen, J. (2000) The Circumstances of Women Enterpreneurs. Denmark, Ministry of Trade and Industry 
11. KK (Khwendo Kore) (2006) Gender Based Action Research Study2003 on Initiating and Implementing Women and Children Development Programmes in FATA (Unpublished Report) Islamabad: CIDA (Page) Pakistan office.

12. Klien, H. G. and Nestvogel, R. (1992) Women in Pakistan. Lahore, Pakistan, Vanguard Bookd Ltd.

13. Loutfi, M. F. (1992) Women Gender and Work. London: Duke University Press

14. Marshall, J. (1995) Women Managers Moving On: Exploring Career and Life Choices. Routledge: London

15. UNDP (United Nations Development Programme) (2003) A Handbook on Gender Mainstreaming Islamabad: Gender Mainstreaming Project, Planning and Development Division and Department

16. Walby, Sylvia, (2003), Gender Transformations Routledge London \& Newyork. 